\title{
Altitudinal and interannual variation in seedling survival of tree species in central Chile: implications for sclerophyllous forest restoration
}

\author{
Variación altitudinal e interanual en la sobrevivencia de plantas de especies arbóreas en Chile central: \\ implicancias para la restauración del bosque esclerófilo
}

\author{
Pablo I Becerra ${ }^{\text {a,b*, Cecilia Smith-Ramírez }}{ }^{\text {c,de, }}$, Juan J Armesto d,f \\ *Corresponding author: ${ }^{a}$ Pontificia Universidad Católica de Chile, Facultad de Agronomía e Ingeniería Forestal, Departamento \\ de Ecosistemas y Medio Ambiente, Av. Vicuña Mackenna 4860, Santiago, Chile, phone/fax: 26864169, pablobecerra@uc.cl \\ ${ }^{\mathrm{b}}$ Center of Applied Ecology and Sustainability (CAPES), Alameda 340, Santiago, Chile. \\ c Universidad de Los Lagos, Departamento de Ciencias Biológicas y Biodiversidad, Osorno, Chile. \\ ${ }^{\mathrm{d}}$ Instituto de Ecología y Biodiversidad (IEB), Las Palmeras 3425, Santiago, Chile. \\ e Universidad Austral de Chile, Facultad de Ciencias Forestales y Recursos Naturales, Instituto de Conservación, \\ Biodiversidad y Territorio, Valdivia, Chile. \\ ${ }^{\mathrm{f}}$ Pontificia Universidad Católica de Chile, Facultad de Ciencias Biológicas, Departamento de Ecología, \\ Alameda 340, Santiago, Chile.
}

\begin{abstract}
SUMMARY
An important issue in ecological restoration of forest ecosystems is to establish where reforestation is more limited by ecological factors and thus where additional treatments (e.g. irrigation, shading) are more needed. Population growth, density and reproduction in plants have frequently been documented to decrease with altitude, although in semiarid regions, initial increases up to middle elevations and then decreasing upward have been reported. In the semiarid region of central Chile, the Andean sclerophyllous forest is distributed between 400 and 1,600 m a.s.1. In this paper, we tested the hypothesis that reforestation in this ecosystem should be more successful at middle elevations of its altitudinal range. We planted twenty seedlings of three shade-intolerant tree species (Lithraea caustica, Quillaja saponaria and Schinus polygamus) in five sites along an elevation gradient (480 to 1,500 m a.s.1.). We repeated the experiment during two consecutive years (2007 and 2008) that had different climatic conditions. Seedling survival for all species was superior at higher elevations in both experimental years, and final survival did not differ between years at any elevation level in the three species. In contrast to our initial prediction, these results suggest that reforestation of the Andean sclerophyllous forest is more successful at higher altitudes, and that at lower altitudes, additional treatments (irrigation, shading, etc.) would be needed to restore these forests.
\end{abstract}

Key words: altitudinal gradient, climate oscillations, restoration, sclerophyllous forest, seedling establishment.

\section{RESUMEN}

Un problema en restauración ecológica de ecosistemas forestales es establecer dónde la reforestación es más limitada por factores ecológicos, y así dónde son más necesarios tratamientos adicionales (riego, sombramiento, etc.) dentro del área de distribución del ecosistema. La densidad, crecimiento poblacional y reproducción en plantas frecuentemente decrece con la altitud, aunque en regiones semiáridas se observan incrementos iniciales hasta niveles altitudinales intermedios, y luego decrecimientos hacia niveles superiores. Así, en regiones semiáridas la reforestación puede ser más exitosa en niveles altitudinales intermedios de los ecosistemas. En este trabajo se evaluó la hipótesis que en el bosque esclerófilo andino (400 a 1.600 m s.n.m., región semiárida de Chile), la reforestación es más exitosa en niveles intermedios de su rango altitudinal. Para esto, fueron plantadas 20 plantas de tres especies arbóreas intolerantes que se encuentran en la mayor parte del rango altitudinal del ecosistema (Lithrea caustica, Quillaja saponaria y Schinus polygamus), en cinco sitios a lo largo de un gradiente altitudinal en Chile central (480 - 1.500 m s.n.m.). Este ensayo fue repetido en dos años consecutivos de diferentes condiciones climáticas (2007 y 2008). La sobrevivencia de plantas de las especies fue superior en altitudes mayores en ambos años, y la sobrevivencia no difirió entre años en ningún nivel altitudinal en cada especie. A diferencia de la hipótesis inicial, estos resultados sugieren que la reforestación del bosque esclerófilo andino puede ser más exitosa en altitudes mayores de su rango altitudinal, y que en menores altitudes probablemente se requieren tratamientos adicionales (riego o sombra) para reforestación y restauración.

Palabras clave: bosque esclerófilo, establecimiento de plántulas, gradiente altitudinal, oscilación climática, restauración. 


\section{INTRODUCTION}

In the last few decades, restoration processes have become more important for the conservation of threatened species and degraded ecosystems (van Andel and Aronson 2006). An important issue in ecological restoration of forest ecosystems is to establish where and under what conditions reforestation is more limited by ecological factors, and thus, to determine where additional treatments such as irrigation, shading, soil amendment, among others, are more needed within the distribution area of a target ecosystem (Valladares and Gianoli 2007). The first step to assess this may be to examine the performance of plants without additional treatments, under different ecological conditions within the distribution range of the ecosystem. Additionally, this knowledge is crucial to distribute economical efforts (van Andel and Aronson 2006).

Within the distribution range of an ecosystem, plant performance of more widely distributed species may vary both spatially and temporally. Particularly, climatic variation in space and time may strongly influence recruitment, survival, growth and reproduction of plant species (Milton 1995, Bunker and Carson 2005). One of the main sources of spatial variability in climate are elevational gradients. Although, many ecological studies have documented how species composition, population density, reproduction, survival and growth vary altitudinally (Ramírez et al. 2006, Gworek et al. 2007, Valle-Díaz et al. 2009), it is less known how the success of reforestation changes along altitudinal gradients within the distribution range of an ecosystem type (Valladares and Gianoli 2007).

The semiarid regions of the world with Mediterraneantype climates contain some of the most severely altered ecosystems and are in particular need of restoration (Valladares and Gianoli 2007). In these regions, water availability is the main abiotic factor limiting plant regeneration and reforestation processes (Fuentes et al. 1986, Holmgren et al. 2001, Gutiérrez et al. 2007, Siles et al. 2010, Becerra et al. 2013). In semiarid regions, usually total precipitation increases with elevation, which, in addition to decreasing mean temperatures, reduces soil evaporation. These results in increased soil moisture and reduced water stress for plants compared to low elevation sites (Barry 1973). Studies conducted in semiarid regions suggest that water deficits at low elevations can have negative effects and produce a harsher environment than that found at higher elevations (Rada et al. 1999, Ramírez et al. 2006). However, increasing elevations usually combine decreasing temperatures, in particular minimal temperatures, shorter growing seasons, and hence near altitudinal limits of distribution ranges temperature regimes may produce a reduction in seedling survival (Ramírez et al. 2006). Therefore, in semiarid regions seedling survival may increase up to middle elevations due to improvements in water soil content, and afterwards decrease upward due to reductions in temperature in spite of enhanced soil moisture (Ramírez et al. 2006).
On the other hand, inter-annual variability in climate is characteristic of semiarid regions (Holmgren et al. 2001). The strongest temporal variation is produced by El Niño Southern Oscillation (ENSO) phenomenon and La Niña, which is the next phase, produces roughly the opposite climate patterns to those found during an ENSO episode (Holmgren et al. 2001). Thus, reforestation success may vary among years with contrasting climatic conditions. In addition, elevational patterns in seedling survival may be modulated by annual climate conditions, however, this has not been assessed yet (but see Holtmeier and Broll 2005).

Currently, the climatic effect on abundance and distribution of species and ecosystems has received particular attention in order to predict the consequences of climate change in vegetation (Bunker and Carson 2005, Holtmeier and Broll 2005, Lenoir et al. 2008). In most semiarid regions, models of climate change predict an increase in aridity and frequency of dry years, which probably has already partially occurred (Randin et al. 2009). Therefore, the study of seedling survival and plant performance during dry years would allow predicting the scenery for plant regeneration in the future (van Andel and Aronson 2006).

The central region of Chile is characterized by two mountain ranges, a Coastal and an Andean range, and between them a central valley approximately at $300-500 \mathrm{~m}$ a.s.l. depending on the latitude. The climate in the central valley is drier than in both mountain ranges, and typically precipitation increases while temperature decreases with elevation in both ranges (Santibáñez and Uribe 1993). The Andean range is characterized by a drier climate than that of the Coastal range and the absence of some typically coastal woody species (Luebert and Pliscoff 2005).

The sclerophyllous forest in Chile is distributed in the central region of the country between $31^{\circ}$ and $37^{\circ} \mathrm{S}$, from sea level up to approximately 1,600 m a.s.l., although above this level other tree species may inhabit in both ranges (Luebert and Pliscoff 2005). The aim of this paper was to study the elevational variability of the seedling survival in degraded areas of the Andean sclerophyllous forest. We assessed this in two climatically contrasting years, which allowed us to explore the role of annual conditions in climate for seedling survival as well as the influence of this interannual variability in the relationship between elevation and seedling survival. We tested the hypothesis that in this semiarid region seedling survival should increase up to middle elevations and then decrease upward (within the altitudinal range of this forest type), and that a moister year should produce larger survival than that produced by a drier year. We tested this with the two most widespread native tree species of this forest, Quillaja saponaria (Mol.) and Lithraea caustica (Mol.) Hook et Arn., and a third similarly distributed, although less abundant species, Schinus polygamus (Cav.) Cabrera. This knowledge will allow establishing in which elevational levels it would be necessary to apply additional treatments to improve the restoration success of forest type. 


\section{METHODS}

Study species. The three species included in this study are distributed from sea level up to about $1,600 \mathrm{~m}$ in the Andean range of the sclerophyllous forest (Rodríguez et al. 1983), and are evergreen species used to reforest open and degraded areas in central Chile. These species have a relatively similar latitudinal range, although $S$. polygamus has a northernmost distribution $\left(31^{\circ} \mathrm{S}\right)$ than that of the other species $\left(32^{\circ} \mathrm{S}\right)$, and similar southern distribution $\left(38^{\circ} \mathrm{S}\right)$ (Rodríguez et al. 1983). These species are considered shade-intolerant mainly when adult, as they are often found growing in shrublands or disturbed areas. However, Q. saponaria and L. caustica are known to regenerate well under nursing shrubs especially in more xeric habitats of central Chile (Fuentes et al. 1986). Quillaja saponaria and $L$. caustica seem to have similar requirements of water and to be resistant to xeric habitats (Martínez and Armesto 1983), though S. polygamus is distributed in more xeric habitats within central Chile (Luebert and Pliscoff 2005, Rodríguez et al.1983), suggesting that this species may be mildly more drought-resistant than the others.

Study area. The study was conducted in the mediterranean region of Chile, in the outskirts of Santiago, in five sites at the same latitude $\left(33^{\circ} \mathrm{S}\right)$. These sites ranged from $480 \mathrm{~m}$ a.s.l. in the central valley (Rinconada), to the upper distribution limit of the species and ecosystem under study, at 1,500 $\mathrm{m}$ a.s.l. (Maitenes, table 1). All sites were on flat areas or hillsides oriented to the north with gentle slopes $(<20 \%)$, without woody vegetation and only an herbaceous layer present.

In this study area, mean annual precipitation increases with elevation (Santibáñez and Uribe 1993), being $286 \mathrm{~mm}$ at $500 \mathrm{~m}$ a.s.1., $371 \mathrm{~mm}$ at $700 \mathrm{~m}$ a.s.1., and $486 \mathrm{~mm}$ at $2,600 \mathrm{~m}$ a.s.l. (values of precipitation reported by meteorological stations located at those elevations, average 19611990, Dirección General de Aguas 2010). In addition, due to the fact that we repeated the experiment in two consecutive years (May 2007-March 2008 and May 2008-March

Table 1. Geographic location and elevation of study sites in central Chile.

Ubicación geográfica y altitud de los sitios de estudio en Chile central.

\begin{tabular}{lllc}
\hline \multicolumn{1}{c}{ Site } & Latitude S & Longitude W & $\begin{array}{c}\text { Elevation } \\
\text { (m a.s.1.) }\end{array}$ \\
\hline Rinconada & $33^{\circ} 29^{\prime} 06^{\prime \prime}$ & $70^{\circ} 52^{\prime} 30^{\prime \prime}$ & 480 \\
Pirque & $33^{\circ} 42^{\prime} 06^{\prime \prime}$ & $70^{\circ} 30^{\prime} 33^{\prime \prime}$ & 860 \\
San Ramón & $33^{\circ} 25^{\prime} 51^{\prime \prime}$ & $70^{\circ} 30^{\prime} 49^{\prime \prime}$ & 919 \\
San Carlos & $33^{\circ} 23^{\prime} 54^{\prime \prime}$ & $70^{\circ} 29^{\prime} 06^{\prime \prime}$ & 1,081 \\
Maitenes & $33^{\circ} 18^{\prime} 39^{\prime \prime}$ & $70^{\circ} 21^{\prime} 16^{\prime \prime}$ & 1,489 \\
\hline
\end{tabular}

2009), some interannual climatic differences were observed between these experimental years along the altitudinal gradient. During the months of the experiment (May-March) in each year, total rainfall was $178 \mathrm{~mm}$ at $500 \mathrm{~m}$ a.s.1., $225 \mathrm{~mm}$ at $700 \mathrm{~m}$ a.s.l. and $438 \mathrm{~mm}$ at 2,600 $\mathrm{m}$ a.s.l. during the first and drier year (2007-2008), and $352 \mathrm{~mm}$ at 500 ma.s.1., 437 $\mathrm{mm}$ at $700 \mathrm{~m}$ a.s.l. and $903 \mathrm{~mm}$ at 2,600 $\mathrm{m}$ a.s.l. during the second and moister year (2008-2009) (Dirección General de Aguas 2010). This indicates an increase of about $50 \%$ in rainfall during the second experimental year. Most precipitation in the region occurs between June and September (Santibañez and Uribe 1993). During the study years, $87 \%$ and $92 \%$ of the precipitation occurred between May and September, in the first and second year respectively.

On the other hand, temperatures patterns were relatively similar between years (Dirección Meteorológica de Chile 2010). At $500 \mathrm{~m}$ a.s.l., mean minimal temperature during the months of the first study year was $2.3{ }^{\circ} \mathrm{C}$, and $2.2^{\circ} \mathrm{C}$ during the second study year. At this elevation, mean maximal temperature during the months of the first study year was $30.1{ }^{\circ} \mathrm{C}$, and $31.5^{\circ} \mathrm{C}$ during the second study year. At $700 \mathrm{~m}$ a.s.l., mean minimal temperature during the months of the first study year was $2.2{ }^{\circ} \mathrm{C}$, and $2.9{ }^{\circ} \mathrm{C}$ during the second study year. At this elevation, mean maximal temperature during the months of the first study year was $30.5^{\circ} \mathrm{C}$, and $31.0^{\circ} \mathrm{C}$ during the second study year. Unfortunately, we did not have temperature data from higher altitudes. However, they were probably lower due to adiabatic reduction. We found similarities between the years at 500 as well as $700 \mathrm{~m}$ a.s.l., hence, at higher altitudes this similarity should also occur.

Soils of the five sites are located on a volcanic parent material, a substrate of andesite and diorite composed by loam to silty loam. Current soil conditions in the five sites result from natural degradation produced by elimination of original woody vegetation and colonization of mainly exotic and some few native herbs.

Experimental design and analyses. We conducted two separated experiments, one between May 2007 and March 2008 (the drier year), and the second one between May 2008 and March 2009 (the moister year). During May of each year, we planted 20 woody seedlings (8-months old) of each of the three woody species studied in the five sites along the altitudinal gradient, 300 plants overall (table 1). All surviving seedlings from the first year were extracted, and in the second experiment, new seedlings were planted again. Each site was fenced $(30 \times 30 \mathrm{~m})$ with mesh wire ( $1.5 \mathrm{~m}$ height) to prevent livestock and rabbit grazing. This limiting ecological factor (herbivory) is widely known to cause mortality and all reforestation processes should include this protection as a minimal treatment to avoid losing plants (Fuentes et al. 1986). Seedlings were separated by $2 \mathrm{~m}$ from one another and species distributed randomly within the fenced area. Seedling heights of all species at time of planting varied between 15.8 and $34.8 \mathrm{~cm}$. 
All seedlings were produced in the greenhouse of University of Chile, Santiago, Chile, and all species received the same nursery treatments. These plants were produced from seeds collected from trees in the area surrounding the study sites, and seeds of various mother plants were mixed before sowing.

Herbs growing within $30 \mathrm{~cm}$ of each seedling were removed manually to control for differences among sites and seedlings. Plants were watered once at the time of planting (approximately $3 \mathrm{~L}$ per plant in $0.25 \mathrm{~m}^{2}$, equivalent to $12 \mathrm{~mm}$ rain). Seedling survival was monitored monthly since the planting date for a total of nine months (from June until March of the following year). A seedling was considered alive when it showed at least one green leaf.

We evaluated soil moisture in each experimental site, in order to assess changes in soil water content (\%) between years and along the elevation gradient. We collected soil samples $\left(500 \mathrm{~cm}^{3}\right.$, top $\left.20 \mathrm{~cm}\right)$ on five separated summer days (January-February of each year) and estimated water content by the gravimetric method for each year and site. Samples were taken from 10 points randomly located at each of the five sites within the $30 \times 30 \mathrm{~m}$ fenced area. Thus, all samples were collected from open sites (without woody cover), and between planted seedlings (not influenced by experimental seedlings). We calculated an average of soil water content for the five days of sampling, and evaluated differences among sites by a factorial ANOVA, with site and year as factors.

We performed GLM analyses (generalized lineal model), with binomial distribution of data (0: seedling dead, and 1: seedling alive) and Logit link function, to compare seedling survival among elevations and between years for each species and season separately. For each species, we first performed a GLM of survival data recorded until December of each year (late spring, before the dry season) to compare spring survival between elevations and years. Then, we performed a second GLM analysis of data recorded until March of each year (late summer, at the end of the dry season) to compare summer survival between elevations and years. All analyses were performed using SPSS 15.0 for windows. Because we only worked with five elevation levels along the altitudinal gradient, we were not able to perform a correlation analysis between elevation and survival. We recognized this limitation to infer about a correlation between these two variables, however, visualizing the survival pattern among elevations as well as significant differences between elevation levels, we propose some suggestions about this relationship.

\section{RESULTS}

Soil water content. Soil water content differed significantly between elevations $\left(\mathrm{F}_{4,90}=13.60 ; P<0.001\right)$ and years $\left(\mathrm{F}_{1,90}=8.742 ; P=0.003\right)$. Interaction between elevations and year was not significant $\left(\mathrm{F}_{4,90}=0.27 ; P=0.898\right)$. Higher elevations presented superior soil water content than that presented by lower elevations (figure 1), and globally, soil water content in summer was significantly more important in the year of higher rainfall than in the drier year. Nevertheless, we did not observe significant differences in soil water content between years at each site separately (Tukey tests, $P>0.05$ ) (figure 1).

Seedling survival. Regarding general effects of elevation (including both years together), seedling survival at the end of the dry season (March) differed significantly between sites located at different elevations for the three target species (table 2, figure 2B, D, F). In general, survival in March was significantly superior in the uppermost site (Maitenes) than in the two lowest sites in both years for the three species (LSD $P<0.05$ ) (figure 2B, D, F). Regarding seedling survival before the onset of the dry season (December), in $Q$. saponaria and L. caustica we observed only marginally significant differences, and in $S$. polygamus we observed no significant difference between elevations when data of both years were analyzed together (general effects of elevation in table 2). Nevertheless, when differences among elevations were examined separately between years, $S$. polygamus survival before the onset of the dry season was significantly more important in the uppermost site, Maitenes, than in the other sites in the first year (LSD tests, $P<0.05$ ) (figure 2A). Likewise, survival in December of Q. saponaria as well as $L$. causti$c a$ was better in the higher than in the lower sites, in these cases in both years (LSD tests, $P<0.05$ ) (figure 2C,E).

On the other hand, regarding general effects of the experimental year (including all elevations together), seedling survival of $L$. caustica and $Q$. saponaria at the end of the dry season (March) did not differ between years (table 2). In turn, in S. polygamus, seedling survival in March was significantly superior in the second year (table 2). In this last case, only in two elevations survival during the moister year was significantly higher than during the drier year (figure 2B). In contrast, seedling survival before the onset of the dry season was significantly higher in the second than in the first year in all three woody species (table 2), which was observed in every elevation and species (figure $2 \mathrm{~A}, \mathrm{C}, \mathrm{E}$ ).

\section{DISCUSSION}

We initially predicted that seedling survival would increase up to mid-elevations, and then survival would decrease upward near the altitudinal limit of these species and forest type (Andean sclerophyllous forest). However, we observed that seedling survival continuously enhanced with increasing elevation for the three species in both years, especially survival after the dry season, which suggests that this may be a persistent pattern in central Chile regardless of annual climatic conditions. Moreover, this increasing survival with elevation was in general observed during both post-dry season and pre-dry season as well. Although 


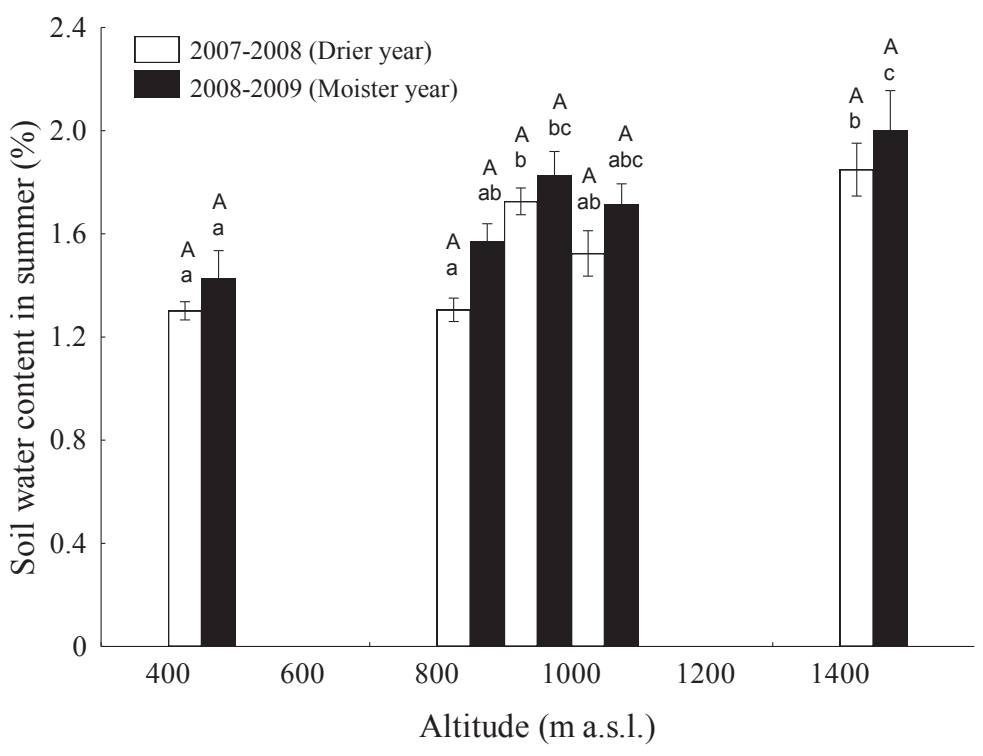

Figure 1. Soil water content during summer months at each elevation (X-axis, $\mathrm{m}$ a.s.1.). Soil water content is the average from $10 \mathrm{measure-}$ ments within each site measured five times between January and February (summer) in 2008 (drier year) and 2009 (moister year). Different lowercase letters indicate significant differences $(P<0.05$, LSD tests) among elevations within a particular year. Different uppercase letters indicate statistically significant differences ( $P<0.05$, LSD tests) between 2008 (drier year) and 2009 (moister year) for a single elevation.

Contenido de agua del suelo durante los meses de verano en cada nivel altitudinal (eje X, m s.n.m.). Valores corresponden al promedio de mediciones en 10 puntos diferentes ubicados aleatoriamente dentro de cada sitio experimental, medidos cinco veces entre enero y febrero de 2008 (verano del año seco) y 2009 (verano del año más lluvioso). Letras minúsculas diferentes indican diferencias significativas $(P<0,05$; prueba LSD) entre altitudes dentro de cada año. Letras mayúsculas diferentes indican diferencias significativas $(P<0,05$; prueba LSD) entre el verano de 2008 (año seco) y el verano de 2009 (año más húmedo) para cada nivel altitudinal por separado.

Table 2. Statistical results of GLM (generalized lineal models, using binomial distribution of data and logit link-function) to assess the effects of year (drier vs. moister) and elevation (sites in table 1), and their statistical interaction, on seedling survival of three sclerophyllous species from central Chile. Plants were planted in June, and statistical analyses of survival were carried at two dates each year: before the onset of the dry season (December) and at the end of the dry season (March).

Resultados de prueba GLM (Modelo lineal generalizado, usando distribución binomial de datos y función logit) para analizar los efectos del año (seco vs húmedo), altitud (sitios), y su interacción estadística, considerando a las plántulas de cada especie como réplicas por sitio. Las plantas se plantaron en junio, y el análisis estadístico de la sobrevivencia fue evaluado antes del comienzo de la estación seca (diciembre) y al final de la estación seca (marzo).

\begin{tabular}{|c|c|c|c|c|c|}
\hline \multirow{2}{*}{ Source of variation per species } & \multirow{2}{*}{ df } & \multicolumn{2}{|c|}{ Survival December } & \multicolumn{2}{|c|}{ Survival March } \\
\hline & & $\mathrm{Chi}^{2}$ & $P$ value & $\mathrm{Chi}^{2}$ & $P$ value \\
\hline \multicolumn{6}{|l|}{ Lithraea caustica } \\
\hline Year & 1 & 30.53 & $<0.001$ & 0.55 & 0.457 \\
\hline Elevation & 4 & 8.09 & 0.088 & 18.17 & $<0.001$ \\
\hline Year x Elevation & 4 & 1.59 & 0.809 & 1.11 & 0.574 \\
\hline \multicolumn{6}{|l|}{ Quillaja saponaria } \\
\hline Year & 1 & 28.69 & $<0.001$ & 0.01 & 0.998 \\
\hline Elevation & 4 & 9.27 & 0.055 & 12.32 & 0.006 \\
\hline Year $\mathrm{x}$ Elevation & 4 & 1.52 & 0.823 & 1.71 & 0.635 \\
\hline \multicolumn{6}{|l|}{ Schinus polygamus } \\
\hline Year & 1 & 31.22 & $<0.001$ & 4.07 & 0.043 \\
\hline Elevation & 4 & 6.93 & 0.139 & 28.51 & $<0.001$ \\
\hline Year x Elevation & 4 & 3.47 & 0.481 & 1.51 & 0.824 \\
\hline
\end{tabular}



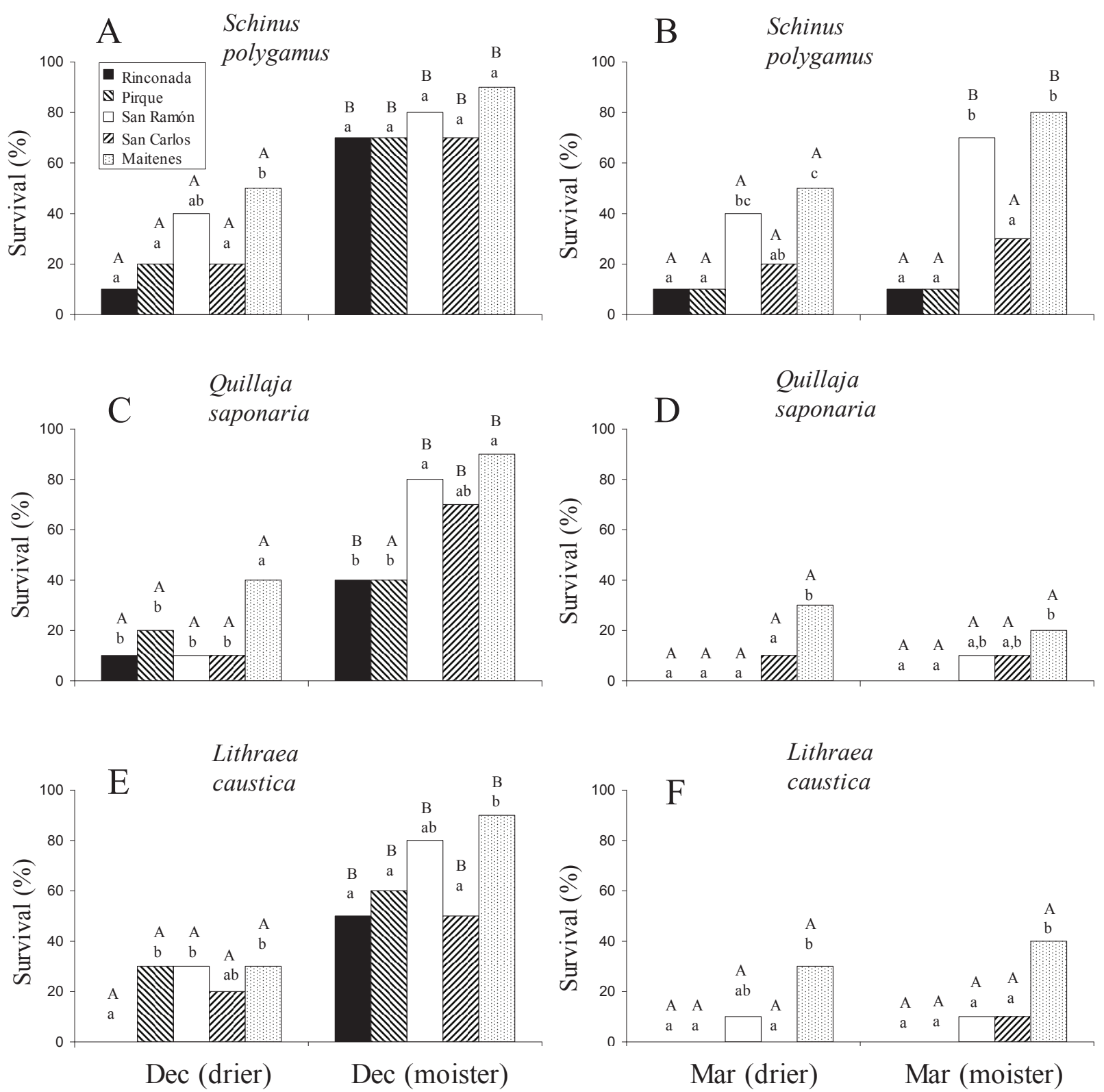

Figure 2. Seedling survival for each site and experimental year in studied species and monitoring dates. Left panels correspond to monitoring during December and right panels to March in each experimental year (drier: 2007-2008, moister: 2008-2009). Sites (bars) are ordered from the altitudinal lower (left) to the higher (right) (see table 1 for values of elevations). Different lowercase letters indicate significant differences $(P<0.05$, LSD tests $)$ among elevations within a particular year and monitoring date. Different uppercase letters indicate statistically significant differences $(P<0.05$, LSD tests) between years for a single elevation and monitoring date.

Sobrevivencia de plantas para cada sitio y año experimental en las especies estudiadas y fechas de monitoreo. Los paneles de la izquierda corresponden al monitoreo de Diciembre y los paneles de la izquierda a Marzo en cada año experimental (más seco: 2007-2008, más húmedo: 20082009). Los sitios (barras) están ordenados desde el altitudinalmente más bajo (izquierda) al más alto (derecha) (ver cuadro 1 para altitudes de cada sitio). Letras minúsculas diferentes indican diferencias significativas $(P<0,05$; prueba LSD) entre sitios de diferentes altitudes dentro de un año y fecha de monitoreo particular. Letras mayúsculas diferentes indican diferencias significativas $(P<0,05$; prueba LSD) entre años para un nivel altitudinal y fecha de monitoreo en particular. 
we were not able to carry out correlation analyses between elevation and survival (because we used only five elevation levels), we observed clear tendencies and significant differences in survival among some elevation levels showing this positive relationship between elevation and survival.

The three species included in this study are distributed from the sea level up to approximately $1,600 \mathrm{~m}$ a.s.l. (Rodríguez et al. 1983). The highest elevation site in the Andean altitudinal gradient studied coincided roughly with the upper limit of distribution of the three target species and forest type, and all these species are more common at low elevations (Luebert and Pliscoff 2005). Therefore, we were surprised to observe that their seedling survival was better near the upper altitudinal limit of their range compared with lower sites (low elevations to mid elevations between 300-800 $\mathrm{m}$ a.s.l. in our study area). We may attribute the higher seedling survival with increasing elevation to the superior soil moisture observed at upper elevation levels in Andean hillsides. Higher elevations received more rainfall (which was observed during the years of the experiment, see study area), temperatures cool adiabatically and increase the number of cloudy days, all this reducing soil evaporation, enhancing soil water content and improving conditions for seedling survival (e.g. Barry 1973). Probably, reductions in temperature along the elevation gradient did not produce negative effects on seedling survival of these species in the higher half of this gradient. Thus, we might speculate that probably the continuous increase in soil moisture with altitude is more important for seedling survival than reduction in temperature, at least within the distribution range of these species and forest type. Nevertheless, we can not rule out that low temperatures contribute to determine the upper limit of distribution in these species at elevations over our higher site. In addition, all sites showed similar degradation and disturbance level, and had been without woody cover for a long time, hence these factors probably did not influence in the elevational pattern.

Seedling survival of the three species at the end of the summer-dry period did not differ between years at any elevation level, except in S. polygamus in only two high elevations. In contrast, seedling survival before the dry season was significantly lower during the first and drier year than in the second and moister year in all elevation levels and species. Major differences in winter rainfall between years (mostly during August) recorded in our study sites likely triggered inter-annual differences in seedling survival during late winter and late spring (December). Instead, strong summer drought during both years probably produced the extremely low and similar post-dry season seedling survival in the two years. Population and community processes often vary in response to climatic oscillations (e.g. Bunker and Carson 2005), and in particular to ENSO rainy years (Squeo et al. 2007). In our case, the study years were strongly different in winter-spring rainfall, and the first year was considered as La Niña event. However, this inter-annual climatic variation did not affect seedling survival measured after the dry season in these species. These results suggest that seedling survival patterns may be more related to low or negligible summer precipitation combined with high temperatures than to winter and spring rainfall. Consistently, similar and extremely dry summers in both years resulted in the lack of significant difference in summer soil water content between years when data from every elevation were separately compared. Thus, although it is known that summer drought represents a stronger bottleneck for seedling establishment, this period seems to be more influential than a rainy winter or spring for seedling survival. This was particularly observed in $Q$. saponaria and $L$. caustica, for which final seedling establishment in central Chile was constrained primarily by summer drought, irrespective of differences in winter or spring rainfall. It is probable that global differences in soil moisture observed during the second summer were not high enough to produce global differences in survival after summer. Similarly, Gutiérrez et al. (2007) and Squeo et al. (2007) in more arid environments of Chile reported that temporal variation in plant recruitment and abundance was more dependent on the intensity of summer drought than on winter precipitation. Nevertheless, for one of the studied species (S. polygamus), at least globally and for two high elevations, post-dry season survival was significantly superior during the second year. This could be related to the fact that this species is more drought resistant than the others, and the increment in rainfall and globally higher soil water content observed during the second year were high enough to increase its survival.

On the other hand, Gutiérrez et al. (2007) and Squeo et al. (2007) proposed to conduct restoration of drylands during rainy ENSO years. Consistent with this, although our second experimental year was moister, it did not correspond to an ENSO event, and it did not produce an enhancement in survival. This suggests that it is probably necessary more precipitation (such as an ENSO event) to produce a significant increase in post-summer seedling survival. Our results also suggest that this may depend on the species as the inter-annual patterns of survival for one of our species (S. polygamus) was different from that of the other species. In all these cases, additional techniques (e.g. irrigation) would be necessary to improve survival of these species during dry or normal years.

During our first experimental year we observed extremely low rainfall compared with the average for the region and lower than that recorded for the second year. Dry years probably will be more common under a scenery of climate change (Randin et al. 2009). Thus, our results support the idea that under future increases in aridity within semiarid ecosystems as consequence of climate change, tree species would have very few opportunities to regenerate at lowlands, and they may only persist at highlands. Similar conclusions have already been proposed by Gworek et al. (2007), Randin et al. (2009) and Valle-Díaz et al. (2009). 
Likewise, other studies have documented that several species have climbed up along elevational gradients as a consequence of recent climate change in the Northern hemisphere (e.g. Lenoir et al. 2008).

Knowledge about the variability in seedling establishment in relation to spatial gradients and temporal fluctuations in climate can be highly relevant to understand the abiotic constraints on species distributions and can provide critical information for conservation and restoration programs (Schrott et al. 2005). Our results suggest that currently, higher elevation sites may be more favorable than low elevations sites for reforestation and restoration of woody species, and that restoration in lowlands should include additional treatments that reduce water stress. This has also been founded in other studies. For instance, ValleDíaz et al. (2009) observed better seedling survival at higher altitudes and proposed that restoration actions should be focused in the altitudinal limit of a Mexican tree species, such as in our study area. Similarly, Gworek et al. (2007) found better survival of a Pinus species at higher altitudes in Nevada (USA).

Finally, our results suggest that reforestation and restoration programs of the Andean sclerophyllous forest should rather plant $S$. polygamus in a first phase as this species showed much better levels of seedling survival in all altitudinal and annual conditions in open areas. In turn, despite $Q$. saponaria and $L$. caustica have been considered shade-intolerant species, there is some evidence that both species need shading or irrigation during the seedling stage to improve their survival (Fuentes et al. 1986, Becerra et al. 2013). This evidence, plus the southernmost distribution limit in these two species, suggests that they need more water than that needed by S. polygamus. Similar results were observed by Becerra et al. (2013) in a coastal area of the sclerophyllous forest. Therefore, if no additional treatment may be used (irrigation, artificial shading), restoration of open areas (such as the one of this study) should start planting S. polygamus, and after growing and producing a semi-continuous cover with this species, they should plant $Q$. saponaria or $L$. caustica.

\section{ACKNOWLEDGMENTS}

Work funded by REFORLAN project ("Restoration of forest landscapes for biodiversity conservation and rural development in the drylands of Latin America"), European Union. We thank PROTEGE organization (San Ramón watershed), EDIEM, Pontificia Universidad Católica de Chile (San Carlos), Faculty of Agronomy, Universidad de Chile (Rinconada), Mr. Gaete (Pirque) and Angloamerican S.A. (Maitenes) for allowing us to work in their lands. JJA and CS acknowledge the support of Fondecyt grant 15010001 to CASEB (Pontificia Universidad Católica de Chile) and Iniciativa Científica Milenio, Chile, grant P05-002 and PFB 23 to the Institute of Ecology and Biodiversity. PB thanks the project CONICYT FB $0002-2014$ (CAPES).

\section{REFERENCES}

Barry RG. 1973. A climatological transect on the east slope of the Front Range, Colorado. Artic and Alpine Research 5: 89-110.

Becerra P, G Cruz, S Ríos, G Castelli. 2013. Importance of irrigation and plant size in the establishment success of different native species in a degraded ecosystem of central Chile. Bosque 34(1):103-111.

Bunker DE, WP Carson. 2005. Drought stress and tropical forest woody seedlings: effect on community structure and composition. Journal of Ecology 93: 794-806.

Dirección General de Aguas. 2010. Boletín información pluviométrica, fluviométrica, estado de embalses y aguas subterráneas. Consultado 5 jun. 2010. Disponible en http://www. dga.cl/productosyservicios/informacionhidrologica/Paginas/default.aspx

Dirección Meteorológica de Chile. 2010. Boletines mensuales climatológicos. Consultado 5 jun. 2010. Disponible en http://www.meteochile.gob.cl/climatologia.php

Fuentes ER, AJ Hoffmann, A Poiani, MC Alliende. 1986. Vegetation change in large clearings: patterns in the Chilean matorral. Oecologia 68: 358-366.

Gutiérrez JR, M Holmgren, R Manrique, FA Squeo. 2007. Reduced herbivore pressure under rainy ENSO conditions could facilitate dryland reforestation. Journal of Arid Environments 68: 322-330.

Gworek JR, SB Vander Wall, PF Brussard. 2007. Changes in biotic interactions and climate determine recruitment of Jeffrey pine along an elevation gradient. Forest Ecology and Management 239:57-68.

Holmgren M, M Scheffer, E Ezcurra, J Gutiérrez, G Mohren. 2001. El Niño effects on the dynamics of terrestrial ecosystems. Trends in Ecology and Evolution 16:89-94.

Holtmeier FK, G Broll. 2005. Sensitivity and response of northern hemisphere altitudinal and polar treelines to environmental change at landscape and local scales. Global Ecology and Biogeography 14: 395-410.

Lenoir J, JC Gégout, PA Marquet, P de Ruffray, H Brisse. 2008. A significant upward shift in plant species optimum elevation during the 20th century. Science 320: 1768-1771.

Luebert F, P Pliscoff. 2005. Sinopsis bioclimática de Chile. Santiago, Chile. Editorial Universitaria. 316 p.

Martínez JA, JJ Armesto. 1983. Ecophysiological plasticity and habitat distribution in three evergreen species of the Chilean matorral. Oecologia Plantarum 4: 211-219.

Milton SJ. 1995. Spatial and temporal patterns in the emergence and survival of seedlings in arid Karoo shrubland. Journal of Applied Ecology 32: 145-156.

Rada F, FA Squeo, A Azócar, HM Cabrera. 1999. Water and carbon relations in the genus Adesmia DC. (Papilionaceae) at different altitudes in the high north-central Chilean Andes. Revista Chilena de Historia Natural 72: 201-211.

Ramírez JM, PJ Rey, JM Alcántara, AM Sánchez-Lafuente. 2006. Altitude and woody cover control recruitment of $\mathrm{He}$ lleborus foetidus in a Mediterranean mountain area. Ecography 29:375-384.

Randin CF, R Engler, S Normand, M Zappa, NE Zimmermann, PB Pearman, P Vittoz, W Thuiller, A Guisan. 2009. Climate change and plant distribution: local models predict highelevation persistence. Global Change Biology 15: 1557- 
1569.

Rodríguez RO, O Matthei, M Quezada. 1983. Flora arbórea de Chile. Concepción, Chile. Editorial Universidad de Concepción. 408 p.

Santibáñez F, J Uribe. 1993. Atlas Agroclimático de Chile. Santiago, Chile. Ministerio de Agricultura, Fondo de Investigación Agraria, CORFO. 66 p.

Schrott GR, KA With, AW King. 2005. Demographic limitations of the ability of habitat restoration to rescue declining populations. Conservation Biology 19: 1181-1193.

Siles G, PJ Rey, JM Alcántara, JM Bastida, JL Herreros. 2010. Effects of soil enrichment, watering and seedling age on establishment of Mediterranean woody species. Acta Oecologica 36: 357-364.
Squeo FA, M Holmgren, M Jiménez, L Albán, J Reyes, J Gutiérrez. 2007. Tree establishment along an ENSO experimental gradient in the Atacama desert. Journal of Vegetation Science 18: 195-202.

Valladares F, E Gianoli. 2007. How Much Ecology Do We Need to Know to Restore Mediterranean Ecosystems? Restoration Ecology 15: 363-368.

Valle-Díaz O, A Blanco-García, C Bonfil, H Paz, R Lindig-Cisneros. 2009. Altitudinal range shift detected through seedling survival of Ceiba aesculifolia in an area under the influence of an urban heat island. Forest Ecology and Management 258:1511-1515.

Van Andel J, L Aronson. 2006. Restoration Ecology. Oxford, UK. Blackwell Publishing. 319 p.

Recibido: 23.03 .15

Aceptado: 17.06.16 
